\title{
Intracellular Partitioning of Androgen Receptor Immunoreactivity in the Brain of the Male Syrian Hamster: Effects of Castration and Steroid Replacement
}

\author{
R. I. Wood ${ }^{\star}$ and S. W. Newman \\ Reproductive Sciences Program, Department of Anatomy and Cell Biology, \\ University of Michigan, Ann Arbor, Michigan, 48109-0616
}

\section{SUMMARY}

The effect of castration and steroid replacement on the intracellular partitioning of the androgen receptor in the brain of the male Syrian hamster was determined using immunocytochemistry. Androgen receptors were visualized using the PG-21 antibody (G. S. Prins) on 46- $\mu \mathrm{m}$ coronal brain sections from hamsters perfused with $4 \%$ paraformaldehyde with or without $0.4 \%$ glutaraldehyde. Control studies confirmed antibody specificity in gonadintact and castrate males. In the normal adult male, androgen receptor immunocytochemistry reveals intense staining confined to the cell nucleus. Castration caused a gradual increase in cytoplasmic labelling within 2 weeks, accompanied by a reduction in nuclear staining intensity in androgen receptor-containing neurons throughout the brain. Cytoplasmic androgen receptor staining was eliminated after treatment of orchidectomized males for only 8 $h$ with exogenous testosterone. Likewise, long-term exposure to testosterone and dihydrotestosterone, a nonaromatizable androgen, maintained nuclear androgen receptor immunoreactivity. However, exposure to low phys- iologic concentrations of estrogen was not effective in this regard. In addition, we determined that nuclear androgen receptor immunoreactivity decreases in response to inhibitory short-day photoperiod, but without an increase in cytoplasmic immunostaining. This appears to be due to the decrease in androgen production by the testis, rather than a direct photoperiodic effect, because testosterone supplementation to short-day males restored the intensity of nuclear androgen receptor immunoreactivity to levels comparable to those in the intact male. These findings are compatible with a new model for the intracellular localization of androgen receptors, in which a subset of unoccupied receptors is located in the cell cytoplasm in the absence of ligand. They further demonstrate the repartitioning of such cytoplasmic receptors, thereby confirming and extending previous observations using biochemical techniques on the regulation of neuronal androgen receptors. (c) 1993 John Wiley \& Sons, Inc. Keywords: castration, steroid replacement, androgen receptors, intracellular partitioning.

\section{INTRODUCTION}

Many aspects of behavior and neuroendocrine function are influenced by gonadal steroids, and the central nervous system is a major target for steroid hormones secreted by the gonads. In the male

Received December 23, 1992; accepted February 18, 1993 Journal of Neurobiology, Vol. 24, No. 7, pp. 925-938 (1993) (C) 1993 John Wiley \& Sons, Inc. CCC 0022-3034/93/070925-14

* To whom correspondence should be addressed.
Syrian hamster, testicular androgens inhibit the secretion of pituitary gonadotropins (Tamarkin, Hutchison, and Goldman, 1976; Turek, 1977), yet are essential for maintaining sexual behavior (Morin and Zucker, 1978). Loss of circulating steroids via castration increases pulsatile release of pituitary gonadotropins (Swann and Turek, 1988), and eliminates mating (Morin and Zucker, 1978). These effects on sexual behavior and neuroendocrine function are presumably mediated by the binding of androgens to specific receptors in the central nervous system. Studies using autoradiogra- 
phy and immunocytochemistry have described the location of brain androgen receptors in males of many species (Sachs and Meisel, 1988), including the Syrian hamster (Doherty and Sheridan, 1981; Wood et al., 1992; Wood and Newman, 1993). In the hamster, androgen receptors are widely distributed in brain nuclei implicated in the control of reproductive behavior and neuroendocrine function, particularly the lateral septum (LSv), bed nucleus of the stria terminalis (BNST), preoptic area, amygdala, and hypothalamus.

In these regions in the gonad-intact male, androgen receptor immunoreactivity, like that of other steroid receptors, is concentrated in the cell nucleus (Wood and Newman, 1993). Until recently it was thought that all unbound receptors were also confined to the nucleus, based upon histologic and biochemical studies of the estrogen receptor by King and Greene (1984) and Welshons, Lieberman, and Gorski (1984). However, within the last few years, several reports have described cytoplasmic staining for estrogen (Blaustein and Turcotte, 1989; Fox et al., 1991; Tobet et al., 1991; Blaustein, 1992; Blaustein et al., 1992), progesterone (Blaustein et al., 1992), and glucocorticoid receptors (Ahima and Harlan, 1991). Although the cell nucleus is still believed to contain the majority of bound and unbound steroid receptors, these studies demonstrated immunoreactivity in axons and dendrites of steroid receptor-containing neurons in the absence of ligand.

The intracellular localization of the androgen receptor has not previously been examined in detail. Furthermore, it is not known if steroids can regulate the partitioning of this receptor between the cell nucleus and cytoplasm. Therefore, in the present study, immunocytochemistry was used to observe the intracellular localization of androgen receptors in the brains of gonad-intact and castrated male Syrian hamsters. To determine if gonadal steroids regulate partitioning of the androgen receptor within cells, we examined the effect of acute and chronic replacement with testosterone or its principal metabolites on intracellular androgen receptor immunoreactivity. In addition, we determined the effect of exposure to inhibitory photoperiod on the location of androgen receptor staining within cells. The present study confirms the nucleus as the dominant site of androgen receptor staining in the gonad-intact male, and reports the existence of cytoplasmic immunoreactivity in the absence of the gonads. Our results indicate that the partitioning of androgen receptors changes in response to gonadal steroids.

\section{MATERIALS AND METHODS}

\section{General Methods}

Adult male hamsters (Mesocricetus auratus) weighing between 90 and $112 \mathrm{~g}$ were purchased from Charles River Laboratories. They were housed in groups of three to six per cage under a long-day photoperiod ( $14 \mathrm{~h}$ light / day), except where indicated. Food and water were provided ad libitum.

\section{Castration and Steroid Replacement}

To determine the effects of orchidectomy and steroid replacement on the intracellular localization of androgen receptor immunoreactivity, we castrated males that were anesthetized with sodium pentobarbital anesthesia $(65 \mathrm{mg} / \mathrm{kg}$ ) via a midline scrotal incision. Because cytoplasmic androgen receptor immunoreactivity develops slowly after castration, males used in control studies to verify the specificity of cytoplasmic immunostaining were perfused 2 weeks after orchidectomy. Additional males were perfused 1 or 4 days or 2 or 4 weeks after castration ( $n=3$ each) to monitor the time course of the appearance of cytoplasmic androgen receptor immunoreactivity. To examine the acute effects of testosterone on the translocation of cytoplasmic androgen receptors to the cell nucleus, we castrated three males 2 weeks prior to perfusion; $8 \mathrm{~h}$ before perfusion each received a Silastic capsule, s.c., (i.d.: $1.98 \mathrm{~mm}$; o.d.: $3.18 \mathrm{~mm}$; Dow Corning, MI) containing $10 \mathrm{~mm}$ of crystalline testosterone. Before implantation, capsules were cleaned in alcohol and preincubated in water overnight to prevent a peak in postimplantation steroid release (Karsch et al., 1973). We chose $8 \mathrm{~h}$ of androgen treatment because this time period induces maximal occupancy of nuclear androgen receptors in castrated male rats (Krey and McGinnis, 1990). In the remaining castrate males, steroids were replaced chronically by means of a Silastic implant inserted s.c. immediately after castration; these males were perfused 1 week later. Capsules were packed with $10 \mathrm{~mm}$ of testosterone ( $n=3), 5 \mathrm{~mm}$ of dihydrotestosterone, a nonaromatizable androgen $(n=3)$, or 2 $\mathrm{mm}$ of estradiol- $17 \beta(n=3)$. These implants maintain physiologic levels of circulating gonadal steroids suffcient to cause negative feedback suppression of gonadotropin secretion under inhibitory photoperiods (Ellis and Turek, 1980). Additional males remained gonad-intact to serve as controls.

\section{Photoperiod Treatment}

Finally, we determined the effects of inhibitory short days and androgen treatment on the intracellular distribution of androgen receptors. Five gonad-intact males were exposed to a short-day photoperiod ( 10:14 h, light / dark $)$. Body weight and testicular index [( $\mathrm{mm}$ length $\times \mathrm{mm}$ width $/ \mathrm{g} \mathrm{BW}) \times 10$ ] were determined weekly. 
After 10 weeks, when testis index reached a nadir, two males were implanted s.c. with a $10-\mathrm{mm}$ Silastic capsule containing testosterone. The three remaining males received no further treatment. All were perfused 1 week later; the testes were weighed, and the brains were processed for immunohistochemistry.

\section{Perfusion}

Hamsters were deeply anesthetized with sodium pentobarbital $(130 \mathrm{mg} / \mathrm{kg})$, and perfused through the aorta with $150 \mathrm{ml}$ of $0.1 \mathrm{M}$ sodium phosphate-buffered saline containing $0.1 \%$ sodium nitrite for vasodilation. This was followed by $250 \mathrm{ml}$ of $0.1 M$ sodium phosphate buffer (PB) containing 4\% paraformaldehyde. To determine if the type of fixative influences the intracellular localization of the androgen receptor, we perfused an additional two intact and two castrate males with $4 \%$ paraformaldehyde containing $0.4 \%$ glutaraldehyde. Brains were removed and post-fixed in the perfusion fixative for $1 \mathrm{~h}$ at room temperature and then cryoprotected overnight in $\mathrm{PB}$ with $20 \%$ sucrose at $4^{\circ} \mathrm{C}$. Coronal brain sections (40-50 $\mu \mathrm{m})$ were cut on a freezing microtome or vibratome, and collected into $\mathrm{PB}$ with $0.1 \%$ sodium azide as a preservative. Sections were stored at $4^{\circ} \mathrm{C}$ until processed for immunocytochemistry.

\section{Antiserum to Androgen Receptor}

To visualize androgen receptors, we used a polyclonal rabbit antibody (gift of Dr. Gail S. Prins, University of Illinois-Chicago) directed against a synthetic peptide corresponding to the first 21 amino acids of the rat androgen receptor (Chang, Kokontis, and Liao, 1988; Lubahn et al., 1988). Details of the isolation and characterization of antibody PG-21 are described in Prins, Birch, and Greene (1991). PG-21 has been validated previously for the study of androgen receptors in the brain of the gonad-intact male Syrian hamster (Wood and Newman, 1993). To determine the specificity of androgen receptor immunostaining in the presence and absence of androgen, we performed control studies on tissues from castrate and gonad-intact males including omission of the primary antiserum, blocking immunostaining with the antigenic peptide, and preincubation with a peptide corresponding to a distant region of the androgen receptor.

\section{Immunocytochemistry}

Free-floating sections were washed three times for $5 \mathrm{~min}$ in PB, and incubated in primary antiserum $(0.5 \mu \mathrm{g} / \mathrm{ml}$ in PB with $0.3 \%$ Triton X-100 and $4 \%$ normal donkey serum) for $48 \mathrm{~h}$ at $4^{\circ} \mathrm{C}$. The sections were washed, and transferred to a biotinylated secondary antibody (donkey anti-rabbit IgG, 1:200; Jackson Immunoresearch Labs) for $1 \mathrm{~h}$ at room temperature. Sections were again rinsed, then incubated for $1 \mathrm{~h}$ in the avidin-biotin horseradish peroxidase (HRP) complex (Vectastain ABC Elite kit, Vector Laboratories). HRP was visualized using nickel chloride-enhanced 3,3'diaminobenzidine (DAB) as the chromagen. Although androgen receptor staining in gonad-intact males developed after only 6 min of exposure to DAB, lengthy DAB incubation (20$60 \mathrm{~min}$ ) was necessary to visualize androgen receptors in castrated males (see Results for the effects of different DAB exposures on immunostaining in intact and castrate males). Sections were mounted onto gel-subbed slides, dehydrated in alcohols and xylenes, and coverslipped with Permount.

\section{RESULTS}

In this study, the brains of gonad-intact and castrate males in the presence and absence of exogenous steroids were examined for nuclear and cytoplasmic androgen receptor immunostaining. Control studies provided evidence that the appearance of cytoplasmic staining in the castrate male does not represent artifactual staining due to tissue processing or postmortem translocation of nuclear receptors. As described below, we determined that the length of DAB incubation did not influence the location of nuclear versus cytoplasmic staining, confirmed antibody specificity in tissues from castrate males, and determined that the type of fixative used did not affect cytoplasmic immunoreactivity. Furthermore, the results of hormonal manipulations on androgen receptor partitioning provided evidence of specific steroidal regulation of receptor localization within the cell.

Interestingly, as reported previously for the estrogen receptor (Blaustein and Turcotte, 1989), the extent of cytoplasmic androgen receptor labelling from castrate males varied in different regions of the limbic system. In ventral premammillary nucleus (PMV), the majority of androgen receptor-positive neurons clearly displayed cytoplasmic staining. This appearance was also characteristic of the ventrolateral septum and paraventricular nucleus (PVN). However, in other regions, such as the ventromedial nucleus of the hypothalamus (VMH), bed nucleus of the stria terminalis, and medial preoptic nucleus (MPN), labelling of cellular processes was evident in many, but not all, androgen receptor-containing neurons. Finally, in the medial amygdaloid nucleus ( $\mathrm{Me}$ ), cytoplasmic staining was found only in a subset of labelled neurons. Examples of cytoplasmic androgen receptor staining in PMV, LSv, PVN, and MPN are shown in Figures 1-8. 

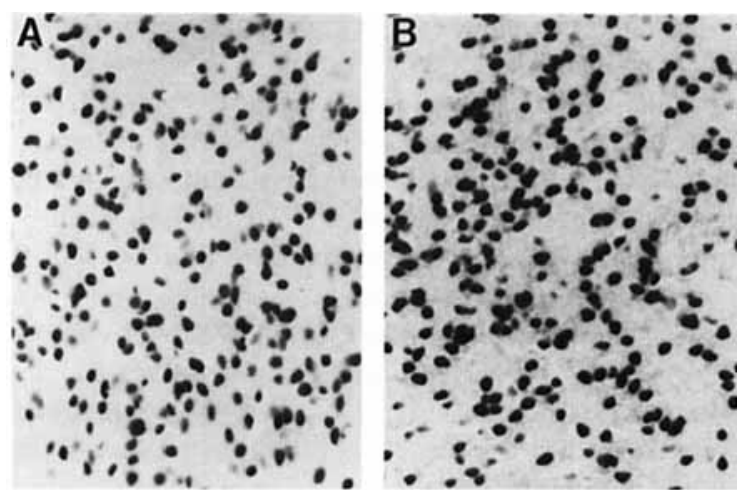

C

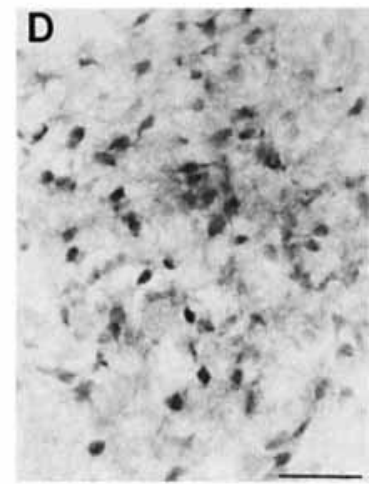

Figure 1 Photomicrographs of androgen receptor immunoreactivity in the ventral premammillary nucleus (PMV) from gonad-intact ( A, B) and orchidectomized male hamsters $(C, D)$. Brain sections were exposed to diaminobenzidine for $6(A, C)$ or $60 \mathrm{~min}(\mathrm{~B}, \mathrm{D})$. Scale bar $=50 \mu \mathrm{m}$.

\section{Duration of DAB Incubation}

To visualize androgen receptor immunoreactivity in brains of castrate males, a modification of our standard immunohistochemical staining protocol was necessary. In the gonad-intact male, incubation in $\mathrm{DAB}$ for 6 min was sufficient to visualize androgen receptor-containing neurons [Fig. 1(A)]. Under these conditions, immunoreactivity in the cell nucleus was robust, with low background staining in other regions of the brain (i.e., cerebral cortex, fiber tracts). In contrast to the intact male, exposure to DAB for $6 \mathrm{~min}$ was inadequate to demonstrate androgen receptor immunoreactivity in brains of castrate male hamsters. Such sections appeared to lack androgen receptors altogether [Fig. 1(C)], an observation similar to that reported by Menard and Harlan (1992). Only when sections were exposed to DAB for $1 \mathrm{~h}$ [Fig. 1 (D)] were androgen receptors evident in brains of castrate males. In these tissues, the receptors were reliably observed in the cytoplasm as well as in the cell nucleus. In contrast, prolonged incubation in DAB did not reveal cytoplasmic localization of the receptor protein in brains of intact males [Fig. 1 (B)], although longer exposure to the chromagen did increase nonspecific background staining in the neuropil.

\section{Specificity of Immunostaining in Intact and Castrate Males}

To establish the specificity of androgen receptor immunostaining in tissues from both intact and castrate males, we conducted control studies. Figure 2(A) illustrates androgen receptor immunoreactivity in the paraventricular nucleus of the hypothalamus of a representative gonad-intact male hamster; Figure 3(A) presents immunostaining in the PVN from a castrated male. In both the presence and absence of androgens, omission of pri-
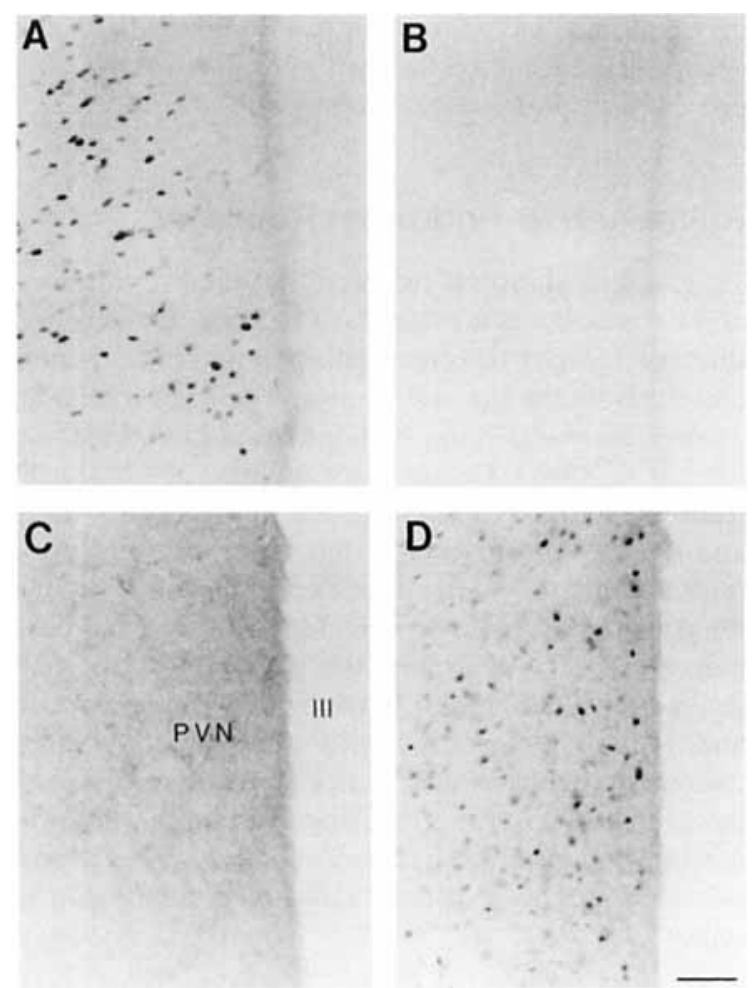

Figure 2 (A) Photomicrograph of androgen receptorimmunoreactive neurons in the paraventricular nucleus of a representative gonad-intact male hamster. Omission of the primary antiserum prevented immunostaining (B), as did preincubation with a $10 \mathrm{M}$ excess of the peptide antigen (C). However, preincubation of the primary antiserum with a synthetic peptide corresponding to amino acids 468-482 did not eliminate immunostaining (D). Scale bar $=50 \mu \mathrm{m}$. 
mary antiserum eliminated staining [Figs. 2(B), 3 (B)], as did preincubation with a $10 \times$ molar excess of the peptide antigen [Figs. 2(C), 3(C)]. However, because the antibody is directed against only a fragment of the native receptor, preincubation of the primary antiserum with a synthetic peptide corresponding to a distant portion of the androgen receptor did not block immunostaining [Figs. 2(D), 3(D)].

\section{Effects of Fixation on Androgen Receptor Immunoreactivity}

As demonstrated in Figures 1-3, perfusion with 4\% paraformaldehyde, a common fixative for routine light microscopic immunocytochemistry, reveals androgen receptors in the cell nucleus of the intact male, as well as additional cytoplasmic receptor im-
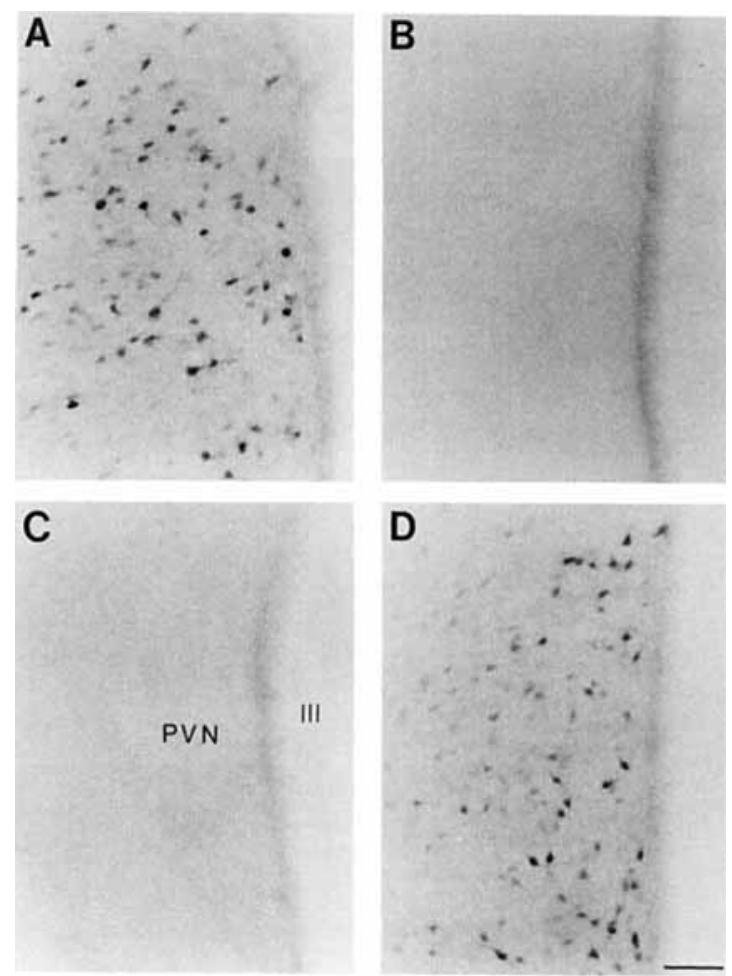

Figure 3 (A) Photomicrograph of androgen receptorimmunoreactive neurons in the paraventricular nucleus of a representative male hamster 2 weeks after orchidectomy. Omission of the primary antiserum prevented immunostaining (B), as did preincubation with a $10 \mathrm{M}$ excess of the peptide antigen (C). However, preincubation of the primary antiserum with a synthetic peptide corresponding to amino acids 468-482 did not eliminate immunostaining (D). Scale bar $=50 \mu \mathrm{m}$.
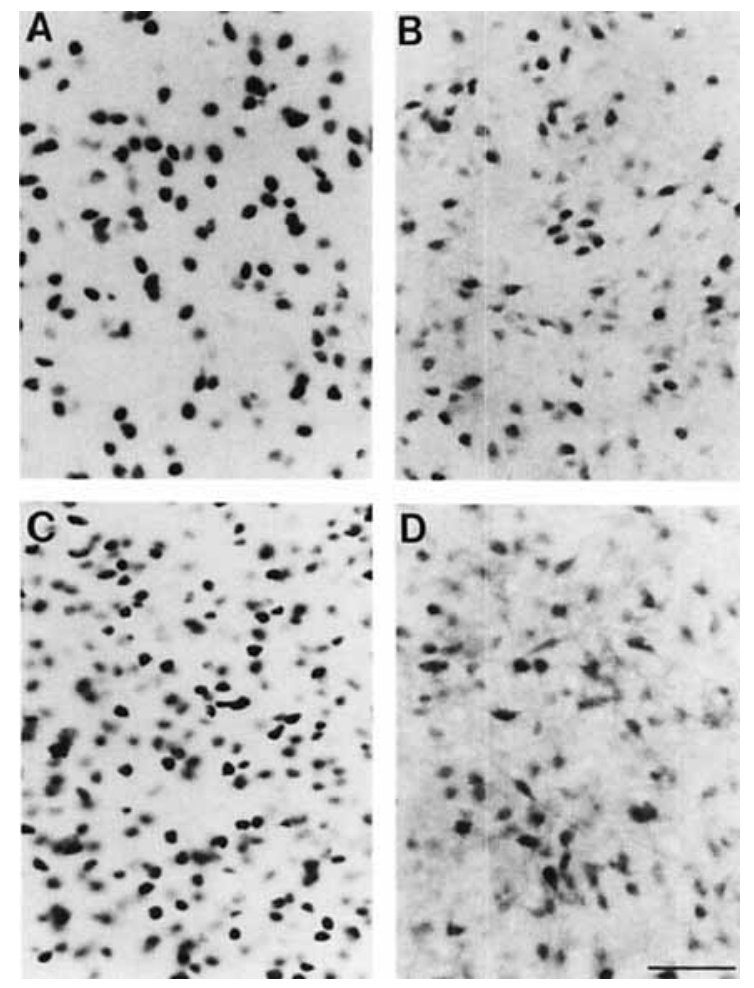

Figure 4 Photomicrographs comparing androgen receptor immunoreactivity in the medial preoptic nucleus (MPN) of gonad-intact (,$C$ ) and orchidectomized male hamsters (B, D) perfused with $4 \%$ paraformaldehyde (A, B), or $4 \%$ paraformaldehyde containing $0.4 \%$ glutaraldehyde $(\mathrm{C}, \mathrm{D})$. Cytoplasmic androgen receptor immunoreactivity was evident in castrate males using either paraformaldehyde or glutaraldehyde fixative. Scale bar $=50 \mu \mathrm{m}$.

munoreactivity in castrate males. This is also shown in Figure 4(A,B) where the diffuse cytoplasmic staining in the processes of cells in the medial preoptic nucleus is clearly seen. However, because the cross-linking of proteins may be reversible at paraformaldehyde concentrations less than 5\% (Baschong, Baschong-Prescianotto, and Kellenberger, 1983), we investigated the effects of $4 \%$ paraformaldehyde in combination with $0.4 \%$ glutaraldehyde on the intracellular localization of the androgen receptor. Glutaraldehyde fixation is considered irreversible (Baschong et al., 1983). As with paraformaldehyde alone, brains from gonadintact animals fixed with glutaraldehyde demonstrated nuclear immunoreactivity in the presence of androgen, but cytoplasmic staining was consistently observed in brains of castrate males [Fig. $4(C, D)]$. Similar findings were obtained in males perfused with Bouin's fixative (data not shown). 

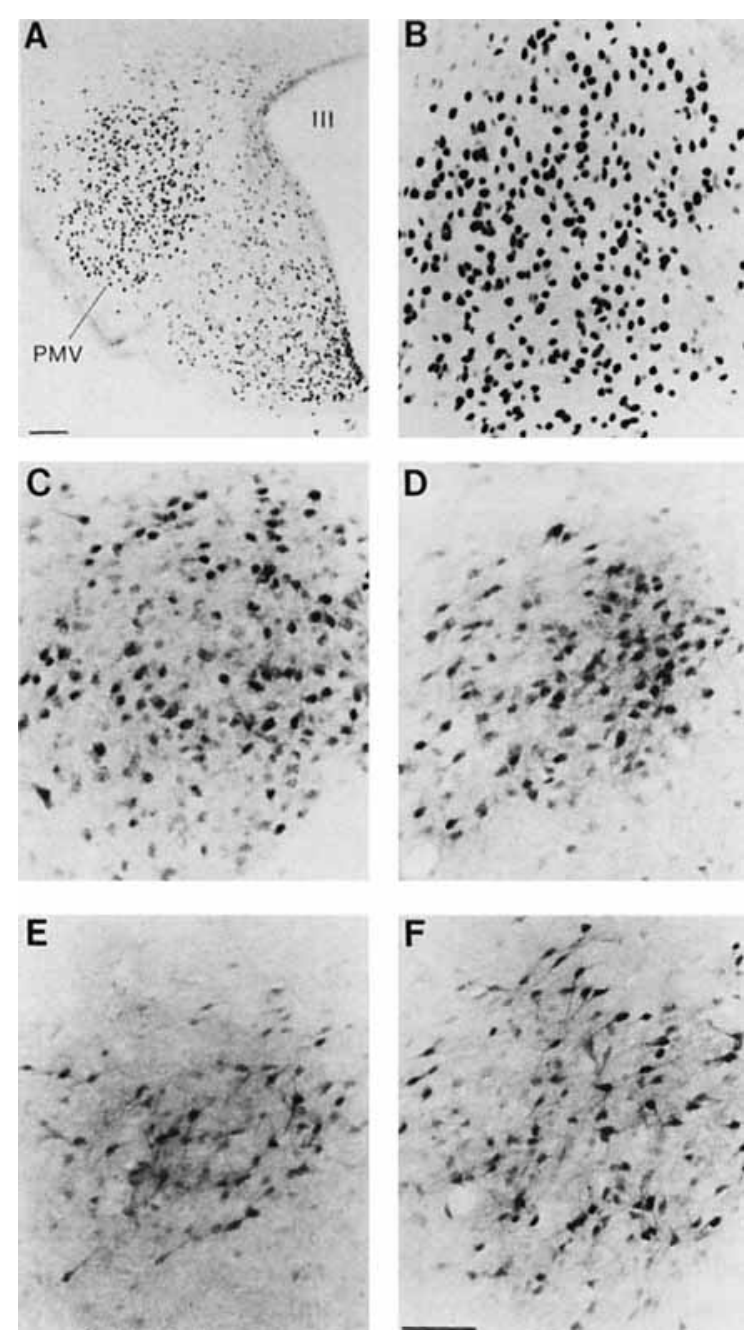

Figure 5 Photomicrographs of androgen receptor immunoreactivity in the ventral premammillary nucleus (PMV) of a representative gonad-intact male hamster at low (A) and high magnification (B), and in PMV of males castrated for 1 day (C), 4 days (D), 2 weeks (E), and 4 weeks (F). Scale bars $=100 \mu \mathrm{m}$ (A), $50 \mu \mathrm{m}$ (B-F).

\section{Time Course of Cytoplasmic Staining after Castration}

From 1 day to 4 weeks after castration, we observed a gradual increase in cytoplasmic androgen receptor immunoreactivity in adult male hamsters, accompanied by loss of dark nuclear staining. This effect was seen in androgen receptor-containing neurons throughout the brain in areas that contain large numbers of androgen-responsive cells. Figure 5 compares androgen receptor-containing neurons in the ventral premammillary nucleus of the hypothalamus of a gonad-intact male [Fig. 5(A,B)] with those of males castrated for 1 day [Fig. 5(C)],
4 days [Fig. 5(D)], 2 weeks [Fig. 5(E)], and 4 weeks [Fig. 5(F)]. Androgen receptor immunoreactivity in intact males was visible as intense labelling confined to the cell nucleus. Effects of castration were visible after only 1 day. In the first few days after castration, staining was predominantly nuclear, although some labelling of cytoplasmic processes was evident. The increase in cytoplasmic labelling was accompanied by a reduction in nuclear staining intensity. Maximal cytoplasmic staining developed within 2 weeks. At 2 and 4 weeks after castration, labelling filled the soma and extended into dendrites. This effect was maintained for at least 12 weeks after orchidectomy (data not shown).

\section{Effects of Acute Testosterone Replacement}

Figure 6 compares the intracellular partitioning of androgen receptor immunoreactivity in MPN of a gonad-intact male [Fig. 6(A,B)], a male castrated
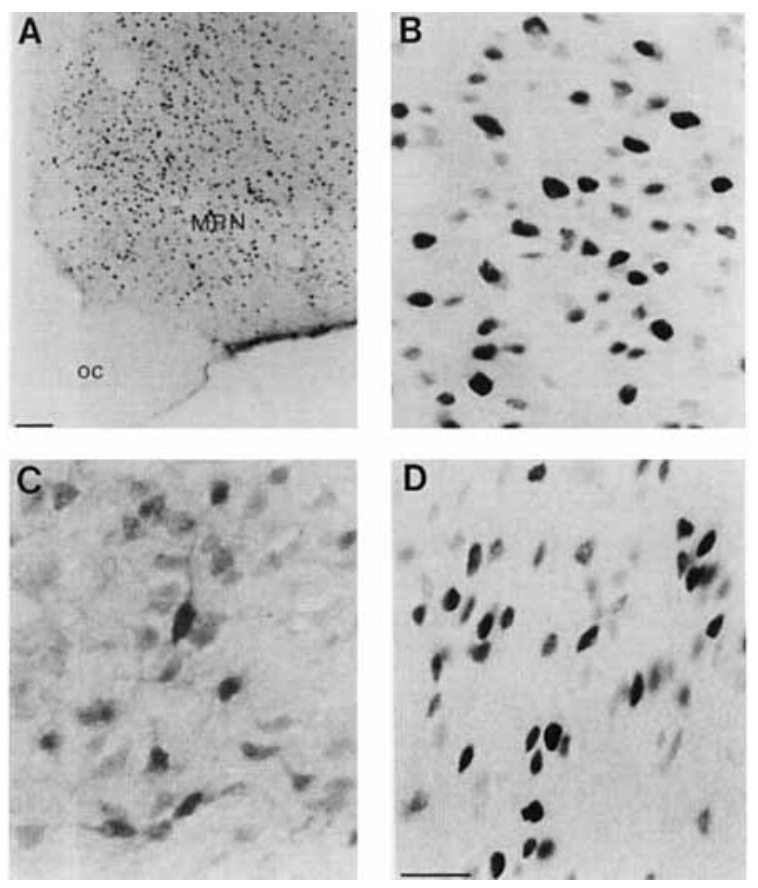

Figure 6 Photomicrographs of androgen receptor immunoreactivity in the medial preoptic nucleus of a representative gonad-intact male hamster at low (A) and high (B) magnification, and of males 2 weeks after castration (C, D). In the continued absence of gonadal steroids (C), androgen receptor immunoreactivity is clearly evident in the cytoplasm. However, labelling is confined to the cell nucleus within $8 \mathrm{~h}$ of treatment with exogenous testosterone (D). Scale bars $=100 \mu \mathrm{m}(\mathrm{A}), 25 \mu \mathrm{m}$ (B-D). 

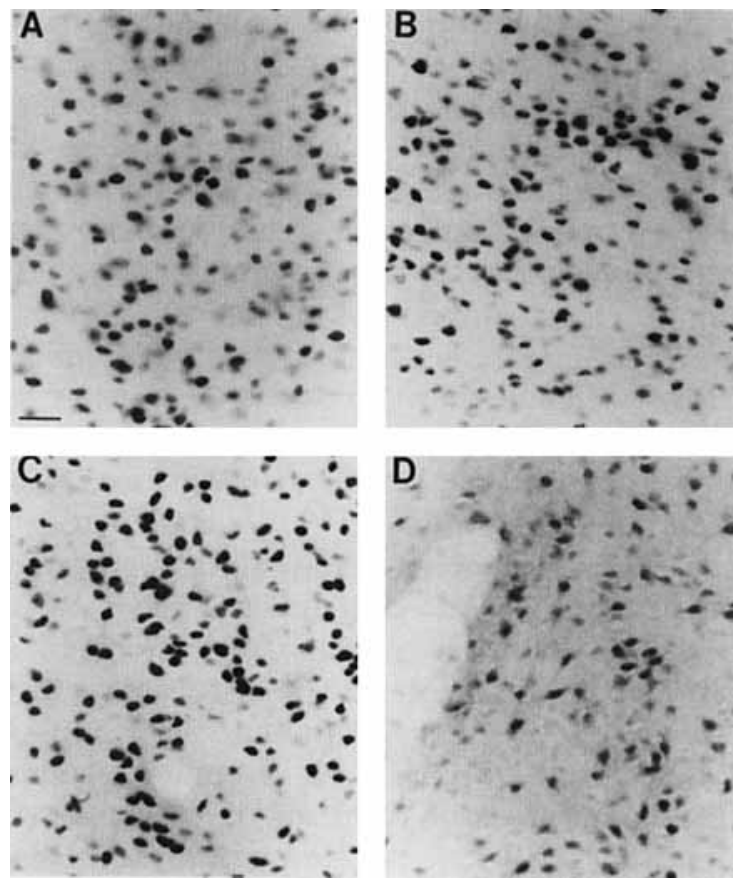

Figure 7 Photomicrographs of androgen receptor immunoreactivity in the medial preoptic nucleus of a representative gonad-intact male hamster (A), and of orchidectomized males replaced with physiologic levels of gonadal steroids (B-D). Males received Silastic capsules of testosterone (B), dihydrotestosterone (C), or estradiol (D). Scale bar $=25 \mu \mathrm{m}$.

for 2 weeks [Fig. $6(\mathrm{C})$ ], and in a 2-week castrate 8 hours after testosterone replacement [Fig. 6(D)]. As described above for PMV, androgen receptor staining was confined to the cell nuclei in gonadintact males. At 2 weeks after castration, cytoplasmic androgen receptors were evident in neurons of MPN. However, within 8 hours after testosterone treatment, staining was again confined to the cell nucleus, in a manner similar to that of the intact male.

\section{Effects of Chronic Steroid Replacement}

The effects of chronic steroid replacement on nuclear versus cytoplasmic androgen receptor labelling in the MPN are presented in Figure 7. When testosterone was replaced at physiologic levels by means of a Silastic implant in orchidectomized males, androgen receptor immunoreactivity was confined to the cell nucleus 1 week later [Fig. 7(B)]. Staining did not appear different from that of gonad-intact males [Fig. 7(A)]. DHT, the principle androgenic metabolite of testosterone, also maintained the nuclear localization of the androgen receptor [Fig. 7(C)]. However, estrogen replacement was ineffective in this regard [Fig. $7(\mathrm{D})]$. Although cytoplasmic staining in castrated, estradiol-treated males was less pronounced than that following castration without steroid replacement, labelled processes were clearly evident in MPN and elsewhere in the limbic system.

\section{Effects of Short-Day Photoperiod and Supplemental Testosterone}

Figure 8 presents photomicrographs of androgen receptor immunoreactivity in LSv from gonad-intact males under long and short photoperiods, and from short-day males receiving supplemental androgen via testosterone implant. After 10 weeks of exposure to short daylengths, paired testis weight averaged $0.76 \pm 0.3 \mathrm{~g}$ (mean \pm S.E.M.), one-third that of males exposed to long days $(2.4 \pm 0.2 \mathrm{~g}, p$ $<0.05)$. This testicular atrophy was accompanied by a marked reduction in androgen receptor immunoreactivity in the brain. Very few androgen receptor-containing neurons were present in LSv, or elsewhere in the brain, and immunoreactivity was faint [Fig. 8(C)]. However, unlike the appearance of neurons after orchidectomy, androgen receptor immunoreactivity in males exposed to short-day photoperiod did not extend into the cytoplasm, but was visualized exclusively in the cell nucleus [Fig. $8(\mathrm{D})]$. To evaluate whether the loss of nuclear androgen receptor immunoreactivity was a direct effect of inhibitory photoperiod on the brain or a secondary response to the loss of circulating androgens, two of the five short-day-treated males received supplemental testosterone. In these hamsters 1 week later, androgen receptor staining in the cell nucleus was robust [Fig. 8(F)], and large numbers of androgen receptor immunoreactive neurons were visible in LSv [Fig. 8(E)] and throughout the brain.

\section{DISCUSSION}

The present study describes the effects of castration and steroid replacement on the intracellular localization of the androgen receptor in the brain of the male Syrian hamster. The androgen receptor protein is visualized exclusively in the neuronal cell nucleus in the gonad-intact male. Castration causes a gradual increase in cytoplasmic labelling that is maximal within 2 weeks, accompanied by a reduction in nuclear staining intensity. Although 

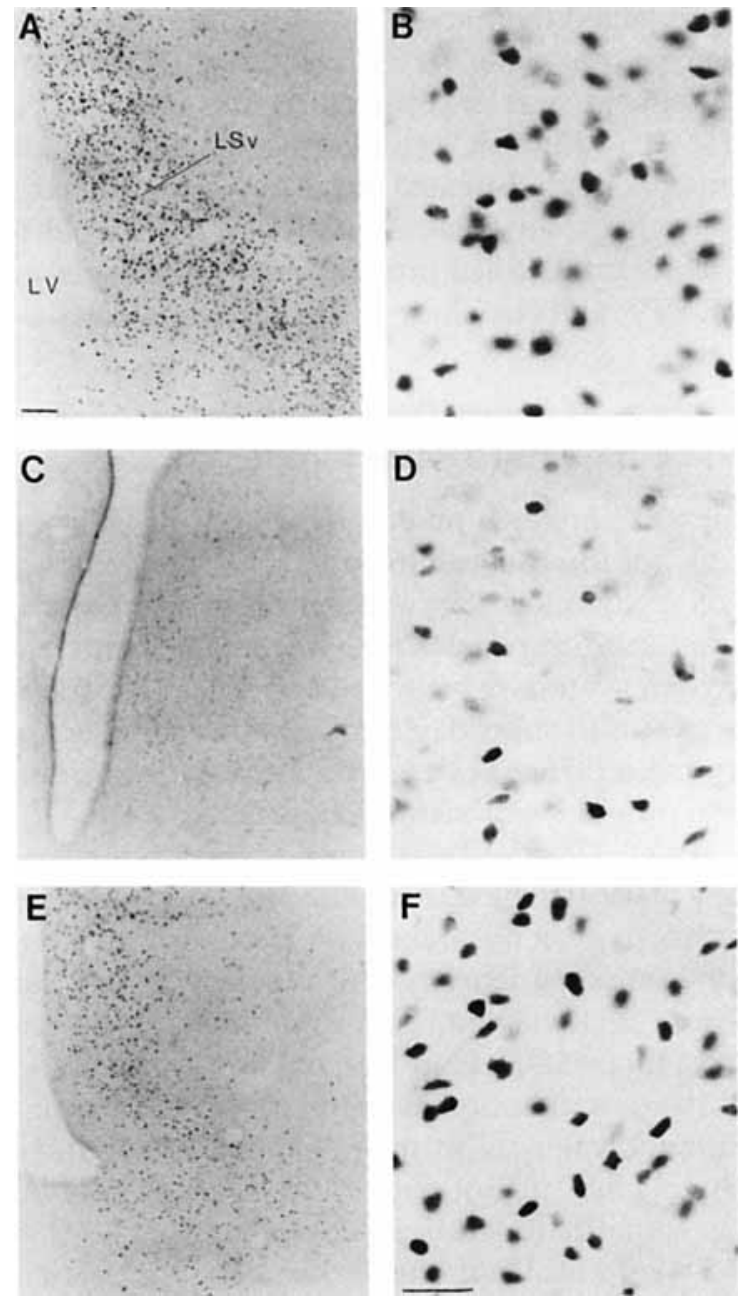

Figure 8 Photomicrographs of androgen receptor immunoreactivity in the lateral septum of a representative male hamster under long-day photoperiod at low (A) and high (B) magnification, and of males exposed to short daylengths for 10 weeks $(\mathrm{C}-\mathrm{F})$. Males exposed to inhibitory photoperiod remained untreated $(C, D)$, or received supplemental testosterone via Silastic implant (E, F). Scale bars $=100 \mu \mathrm{m}(\mathrm{A}, \mathrm{C}, \mathrm{E}), 25 \mu \mathrm{m}(\mathrm{B}, \mathrm{D}, \mathrm{F})$.

this cytoplasmic immunoreactivity in the castrated male is rapidly reversed by exogenous testosterone or long-term exposure to DHT, a nonaromatizable androgen, estrogen replacement at physiologic levels does not maintain the nuclear localization of the androgen receptor. Exposure to inhibitory short-day photoperiod also decreases androgen receptor immunoreactivity in the cell nucleus. However, unlike the effects of castration, loss of nuclear androgen receptor immunoreactivity in brains of short-day-treated males is not accompanied by increased cytoplasmic staining. This effect of short photoperiod appears to be due to the decrease in androgen production by the testis, rather than a direct photoperiodic effect on androgen receptorcontaining neurons, because testosterone supplementation to short-day males restores nuclear androgen receptor immunoreactivity. These findings using immunocytochemistry confirm and extend previous observations on the intracellular partitioning of steroid receptors in the brain.

We have recently described the location of androgen receptor immunoreactive neurons in selected brain nuclei from gonad-intact male hamsters using the PG-21 antibody (Wood and Newman, 1993). In both that earlier study and this present investigation, androgen receptor-containing neurons were found in the same regions as reported for the hamster brain using autoradiography for tritiated testosterone (Wood et al., 1992) or dihydrotestosterone (Doherty and Sheridan, 1981; Wood et al., 1992). Androgen receptor-containing neurons are especially numerous in the lateral septum, bed nucleus of the stria terminalis, medial preoptic area, ventral premammillary nucleus, medial amygdaloid nucleus, and in the ventromedial and arcuate nuclei of the hypothalamus. As determined in the present study, castration does not appear to influence the location of androgen receptor-positive neurons. Recent studies with similar androgen receptor antibodies have described the distribution of androgen receptor-containing neurons in the brain of the rat (Sar et al., 1990; Clancy, Bonsall, and Michael, 1992), monkey (Clancy et al., 1992), and quail (Balthazart et al., 1992). Although the pattern of androgen receptor immunoreactivity and the number of immunoreactive neurons we have described previously in the hamster brain (Wood and Newman, 1993) agrees well with that reported for other mammals, the intracellular location of receptors for steroid hormones has become controversial in recent years.

Originally, based upon biochemical studies involving the extraction of nuclear and cytoplasmic fractions, a "two-step" model of steroid receptor action was proposed wherein the free receptors were present in the cell cytoplasm and were translocated into the nucleus upon steroid binding (Gorski et al., 1968). However, this view was revised based upon the studies of King and Greene (1984) and Welshons et al. (1984) demonstrating that the majority of both bound and unbound estrogen receptors were present within the cell nucleus. Since those observations, many studies have confirmed the predominantly nuclear localization of progesterone (Gasc, Delahay, and Baulieu, 1989), estrogen (Liposits et al., 1990), glucocorti- 
coid (Brink et al., 1992), and androgen receptors (Tan et al., 1988; Husman et al., 1990; Sar et al., 1990). According to this model, it is thought that binding of the receptor to its ligand induces a tight association of the hormone receptor complex with nuclear chromatin, whereas unbound receptors are more readily displaced from the cell nucleus (Gorski et al., 1986). Thus, the abundant steroid receptors measured in preparations of cell cytosol have been considered an artifact of cell fractionation.

More recently the question of cytoplasmic steroid receptors has been revisited, and a new model of receptor localization is emerging. Blaustein and Turcotte reported in 1989 the presence of cytoplasmic receptors for estrogen in the female guinea pig brain. This has been subsequently confirmed for the estrogen receptor in a variety of species (Fox et al., 1991; Tobet et al., 1991; Blaustein, 1992; Blaustein et al., 1992) at the light and electron microscopic levels, and for the progesterone and glucocorticoid receptors as well (Blaustein et al., 1992; Ahima and Harlan, 1991). Unlike the original "two-step" model, these recent observations confirm the cell nucleus as the primary site of steroid receptors. Nonetheless, using highly sensitive staining techniques, immunoreactivity can be demonstrated not only in the cell soma, but in dendrites and axonal processes of steroid receptor-containing neurons (Blaustein and Turcotte, 1989; Blaustein et al., 1992; Blaustein, 1992).

Previous studies of androgen receptor immunoreactivity have reported no evidence of cytoplasmic immunoreactivity ( Tan et al., 1988; Husman et al., 1990; Sar et al., 1990), or very limited cytoplasmic staining (Balthazart et al., 1992; Clancy et al., 1992). The present study demonstrates that, like the other major classes of steroid hormone receptors, androgen receptors are detectable in the cell cytoplasm in the absence of ligand, and that androgens themselves may regulate the partitioning of free receptors between the two cellular compartments. However, the present findings are compatible with the concept that the majority of androgen receptors remain in the nucleus. Because cytoplasmic androgen receptor immunoreactivity is faint compared with that in the nucleus, earlier studies reporting an exclusively nuclear localization of androgen receptors may have employed relatively less sensitive techniques or potentially disregarded light cytoplasmic immunostaining. Additionally, the length of time after castration may play some role; cytoplasmic androgen receptor immunoreactivity appears to develop over several days following orchidectomy. As in the present study, previous studies have reported decreased nuclear androgen receptor immunoreactivity in tissues from castrate males (Husman et al., 1990; Sar et al., 1990). Indeed, a report from Menard and Harlan (1992) using the same antibody reported no evidence of androgen receptor immunoreactivity in the castrated male rat. We suggest that the decreased immunoreactivity in the castrate compared to the gonad-intact male may result from a combination of receptor dilution in the larger cytoplasmic compartment and loss of protein due to destabilization of the receptor in the absence of ligand (Blok et al., 1991).

It has been argued that cytoplasmic immunostaining of steroid receptors is due to passive diffusion of unbound receptors from the cell nucleus during tissue processing (Brink et al., 1992). Although the efflux of free nuclear receptors into the cytoplasm is an energy-independent process (Guiochon-Mantel et al., 1991), and has been demonstrated for the glucocorticoid receptor in unfixed tissue sections prior to immunostaining (Gasc et al., 1989), several factors refute such artifactual leakage in the present study. First, we used perfusion fixation, rather than postmortem immersion, to rapidly immobilize neuronal proteins. Cytoplasmic immunoreactivity was retained even when the brains were fixed with $0.4 \%$ glutaraldehyde, an irreversible fixative (Baschong et al., 1983), and stained in the absence of detergent. Furthermore, we observed androgen receptor immunoreactivity filling neuronal processes at a considerable distance from the cell nucleus, whereas passive diffusion would be more likely to result in a perinuclear "halo" of cytoplasmic staining. Finally, cytoplasmic staining in neurons of castrated males can be blocked under the same conditions that eliminate nuclear immunoreactivity in the gonad-intact male. The antibody used in the present study is directed against the first 21 amino acids of the androgen receptor, a part of the A/B region of the protein (Janne and Shan, 1990). Although the exact function of this portion of the receptor is not known, it shows the most variability among members of the steroid receptor superfamily, and hence, is highly immunogenic (Janne and Shan, 1990 ). Results of control experiments in the present study support the conclusion that the PG-21 antibody is specific for the $\mathrm{N}$-terminal region of the androgen receptor in the presence and absence of ligand. This indicates that the cytoplasmic immunoreactivity in the castrate male is not due to nonspecific staining during prolonged $\mathrm{DAB}$ exposure. 
Together, these observations suggest that androgen receptors are normally present, albeit in small quantities, in the neuronal cell cytoplasm in the absence of androgen.

The present study extends our understanding of cytoplasmic steroid receptors by demonstrating the physiologic regulation of intracellular receptor partitioning. Our data suggest that androgens themselves determine the partitioning of their receptors between the site of receptor synthesis in the cytoplasm, and the site of androgen action in the nucleus. It is has been previously shown that estrogen treatment of ovariectomized female guinea pigs eliminates cytoplasmic estrogen receptor immunoreactivity (Blaustein and Turcotte, 1989). We have now determined the time course of autologous regulation of intracellular androgen receptor partitioning, as well as the effects of exposure to different steroids and inhibitory photoperiods.

Our findings complement those of studies using biochemical techniques to separate bound and free androgen receptors in nuclear and cytoplasmic fractions from neural tissue (Roselli, Handa, and Resko, 1989). Changes described in these biochemical studies in the relative numbers of bound and unbound androgen receptors following steroid manipulations mirror the changes we have described for intracellular receptor localization. In the intact male, a greater proportion of androgen receptors are present in nuclear extracts (Roselli, 1991), presumably reflecting enhanced receptor binding due to high levels of endogenous androgens in circulation. This is consistent with the nuclear localization of the androgen receptor using immunocytochemistry. At 1 week after removal of steroids, there is a decrease in the number of nuclear receptors, accompanied by increasing levels of free receptor in the cytoplasm (Roselli, 1991). This corresponds to the gradual increase in cytoplasmic immunoreactivity in our hamsters after castration. In addition, androgen receptor protein in cultured cells is unstable in the absence of androgen (Syms et al., 1985; Grino, Griffin, and Wilson, 1990), thereby leading to a decrease in the total number of receptors in the castrated male (Fiorelli et al., 1989). These results support our observation that the intensity of androgen receptor immunoreactivity is much less in the absence of steroids, than it is in the intact or androgen-treated male.

In contrast to the gradual appearance of androgen receptor in the cytoplasm after castration, androgen treatment restores receptors to the nucleus within hours. In our study, $8 \mathrm{~h}$ after testosterone treatment, androgen receptor immunoreactivity did not appear different from that of intact males. This finding is consistent with results obtained using a nuclear receptor exchange assay in the rat (Krey and McGinnis, 1990) and guinea pig (Toyooka et al., 1991). In the rat, nuclear androgen receptor occupancy was half-maximal after 30 min of exposure to testosterone, and reached peak levels within $8 \mathrm{~h}$ (Krey and McGinnis, 1990). The initial increase in occupied nuclear receptors presumably reflects binding of existing receptors, whereas maximal androgen receptor binding is thought to include de novo synthesis of additional receptors (Handa, Stadelman, and Resko, 1987). Such newly synthesized receptors could account for the increased intensity of nuclear staining following acute testosterone treatment.

The reduction in nuclear androgen receptor immunoreactivity that we observed in the absence of steroids is a physiologic response, as evidenced by the loss of immunoreactive neurons and lower staining intensity in males exposed to inhibitory short-day photoperiod. It has been long known that exposure to short days suppresses the activity of the reproductive neuroendocrine axis in the male hamster, thereby leading to testicular regression (Bartke, 1985). Involution of the testes is associated with reduced secretion of pituitary gonadotropins, and hence, gonadal steroids (Bartke, 1985 ). Previous studies using biochemical methodologies examined the effects of inhibitory photoperiods on androgen receptors in the brain. According to their findings, short-day photoperiods decrease nuclear androgen receptor occupancy (Bittman and Krey, 1988). This is consistent with the results of the present study, in which we observed reduced nuclear immunoreactivity in males exposed to short days for 10 weeks. Two explanations could account for these findings: either this is a direct, neurally mediated effect of the inhibitory photoperiod on androgen receptors, or the changes observed are secondary to low serum testosterone concentrations induced by short daylengths. Our observation that androgen receptor immunoreactivity is dramatically increased in short-day males with supplemental testosterone supports the latter interpretation, in agreement with Bittman and Krey (1988), who restored nuclear androgen receptor occupancy to intact levels in short-day males treated with physiologic concentrations of testosterone. Furthermore, these results suggest that the loss of androgen receptors in response to short days cannot account for the photoperiodic suppression of gonadotropin secretion, as has been proposed previously (Stankov et al., 1989). 
Nonetheless, it was somewhat surprising to us that the loss of nuclear androgen receptor immunoreactivity in short-day males was not accompanied by increased cytoplasmic staining since biochemical measurements have indicated an increase in the number and affinity of cytoplasmic androgen receptors in short-day males (Stankov et al., 1989). Our findings of decreased immunoreactivity but persistent nuclear localization may be a result of the continued low-level secretion of androgen during photoperiodic inhibition. This low-level testosterone production under short daylengths is certainly physiologically meaningful; although concentrations in the photosuppressed male are inadequate for the expression of mating behavior, very low secretion of androgens does inhibit gonadotropin secretion because sensitivity of the reproductive neuroendocrine axis to testosterone feedback actually increases under inhibitory photoperiod (Bartke, 1985). Thus, the results of the present study provide the first anatomical evidence to support the concept that photoperiodic inhibition of reproduction is not equivalent to castration.

The repartitioning of unoccupied androgen receptors is not restricted to testosterone. Both testosterone and DHT maintained nuclear androgen receptor immunoreactivity in the castrate male, consistent with previous reports in the rat (Handa, Reid, and Resko, 1986; Krey and McGinnis, 1990; Roselli, 1991) and guinea pig (Toyooka et al., 1991) that exogenous androgens increase nuclear receptors and decrease those in the cytoplasm. This suggests that nonsteroidal testicular hormones (i.e., inhibin, activin) do not play a significant role in the regulation of androgen receptor partitioning. In contrast to the effects of androgens, the role of estrogen in the intracellular localization of the androgen receptor remains unclear. In the present study, low physiologic levels of estradiol did not maintain nuclear androgen receptor immunoreactivity. This observation suggests that estrogen fails to influence the androgen receptor at physiologic concentrations, a finding supported by biochemical studies in the guinea pig (Toyooka et al., 1991). However, because estrogen does bind to the androgen receptor, albeit with considerably lower affinity (Chamness, King, and Sheridan, 1979), higher doses of estradiol may affect the partitioning of the androgen receptor. This question remains to be investigated.

The possible influence of estrogen on androgen receptors is not an academic question. Estrogens have diverse actions on sexual behavior and neuroendocrine function in the male. Both androgens and estrogens can inhibit gonadotropin secretion (Ellis and Turek, 1980) and activate certain elements of sexual behavior (Powers, Bergondy, and Matochick, 1985). Furthermore, receptors for androgens and estrogens are found within the same brain nuclei (Sar and Stumpf, 1973; Sheridan, 1978; Commins and Yahr, 1985; Simerly et al., 1990; Wood et al., 1992). However, neuroendocrine function and sexual behavior are not equally responsive to estrogen action. Whereas gonadotropin secretion under short-day photoperiod is exquisitely sensitive to estradiol inhibition (Ellis and Turek, 1980), much higher concentrations of estrogens are required to activate mounting behavior in the castrated male hamster (Powers et al., 1985 ). One explanation is that the neuroendocrine effects of estrogen are mediated through the estrogen receptor, while behavioral effects may also include the binding of estrogen to the androgen receptor. According to this hypothesis, small amounts of estrogen in circulation (Handa et al., 1986) or converted from testosterone via local aromatization (Hutchison et al., 1991) activate specific estrogen receptor-containing neurons within the neural pathways controlling secretion of GnRH. This physiologic action of estrogen in the male is supported by increased secretion of $\mathrm{LH}$ and FSH when endogenous estradiol is blocked (Bartke et al., 1978). However, high levels of estrogens may activate mounting by actions on androgen receptor-containing neurons. This hypothesis remains to be tested.

The results presented in the present study suggest that androgen receptor repartitioning is not a mechanism underlying the differences in behavioral and neuroendocrine responses to steroid manipulation. The transition between nuclear and cytoplasmic receptors appears to be regulated in a similar fashion throughout the brain, in areas containing GnRH neurons (rostral MPN) as well as in areas controlling sexual behavior (Me, BNST, and caudal MPN). However, testosterone has both inhibitory effects on gonadotropin secretion, as well as facilitatory actions on sexual behavior (Bartke, 1985 ). Furthermore, the time course of the response to androgen varies: after castration, gonadotropins increase within days (Tamarkin et al., 1976), whereas ejaculation persists for weeks (Morin and Zucker, 1978). Because of the diverse actions of steroids in the brain, the response to androgens cannot be explained merely by the intracellular localization of the steroid receptor. Instead, the stimulatory and inhibitory effects of androgens may be determined by the transmitter 
content and connections of steroid-concentrating neurons.

At the present time, we can only speculate as to the function of cytoplasmic steroid receptors. It is intriguing that cytoplasmic immunoreactivity in castrate males is not observed uniformly in all androgen receptor-positive neurons, but instead is evident in scattered neurons within any particular brain region. This uneven distribution, which is characteristic of estrogen receptors as well (Blaustein and Turcotte, 1989), may indicate the presence of functionally diverse subpopulations of steroid receptor neurons. Alternatively, those neurons with distinct cytoplasmic staining may simply possess more of the receptor protein. Androgen receptors in the perinuclear cytoplasm may represent newly synthesized proteins that have not been translocated yet to the nucleus, although immunoreactivity is also present in axons and other areas lacking protein synthetic capabilities (Blaustein et al., 1992). Finally, it has been proposed that these receptors may be responsible for the nongenomic actions of steroids, possibly including regulation of neurotransmitter release and synapse formation in the brain (Blaustein, 1992).

The authors thank Dr. Gail S. Prins of the University of Illinois-Chicago for the androgen receptor antiserum, Ms. R. Kaye Brabec, and Ms. Lorita Dudus of the Reproductive Sciences Program Morphology Core Facility (P30-HD-18258) for assistance with tissue processing, and Mr. Stephen E. Asmus and Ms. Sara S. KollackWalker for their critical evaluation of this manuscript. This work was supported by research and training grants from the NIH (NS-20629, HD-07514).

\section{REFERENCES}

AHIMA, R. S. and HaRlan, R. E. (1991). Differential corticosteroid regulation of Type II glucocorticoid receptor-like immunoreactivity in the rat central nervous system: topography and implications. Endocrinology 129 (1):226-236.

Balthazart, J., Foidart, A., Wilson, E. M., and BALL, G. F. (1992). Immunocytochemical localization of androgen receptors in the male songbird and quail brain. J. Comp. Neurol. 317:407-420.

BARTKE, A. (1985). Male hamster reproductive endocrinology. In: The Hamster: Reproduction and Behavior. H. I. Siegel, ed. Plenum Press, NY, pp. 73-98.

Bartke, A., Mason, M., Dalterio, S., and Bex, F. (1978). Effects of tamoxifen on plasma concentrations of testosterone and gonadotropins in the male rat. J. Endocrinol. 79(2):239-240.

Baschong, W., Baschong-Prescianotto, C., and
Kellenberger, E. (1983). Reversible fixation for the study of morphology and macromolecular composition of fragile biological structures. Eur. J. Cell Biol. 32:1-6.

BitTMAN, E. L. and KREY, L. C. (1988). Influences of photoperiod on nuclear androgen receptor occupancy in neuroendocrine tissues of the golden hamster. Neuroendocrinology 47:61-67.

Blaustein, J. D. (1992). Cytoplasmic estrogen receptors in rat brain: immunocytochemical evidence using three antibodies with distinct epitopes. Endocrinology 131 (3):1336-1342.

Blaustein, J. D. and TURCotTe, J. C. (1989). Estrogen receptor-immunostaining of neuronal cytoplasmic processes as well as cell nuclei in guinea pig brain. Brain Res. 495:75-82.

Blaustein, J. D., Lehman, M. N., Turcotte, J. C., and GREENE, G. (1992). Estrogen receptors in dendrites and axon terminals in the guinea pig hypothalamus. Endocrinology 131 (1):281-290.

Blok, L. J., Bartlett, J. M. S., Bolt-De VRies, J., Themmen, A. P. N., Brinkmann, A. O., WeinBauer, G. F., Nieschlag, E., and Grootegoed, J. A. (1991). Regulation of androgen receptor mRNA and protein in the rat testis by testosterone. J. Steroid Biochem. Mol. Biol. 40(1-3):343-347.

Brink, M., Humbel, B. M., De Kloet, E. R., and Van DRIEL, R. (1992). The unliganded glucocorticoid receptor is localized in the nucleus, not in the cytoplasm. Endocrinology 130(6):3575-3581.

Chamness, G. C., King, T. W., and Sheridan, P. J. (1979). Androgen receptor in the rat brain-assays and properties. Brain Res. 161:267-276.

Chang, C., Kokontis, J., and LiaO, S. (1988). Structural analysis of complementary DNA and amino acid sequences of human and rat androgen receptors. Proc. Natl. Acad. Sci. USA 85:7211-7215.

Clancy, A. N., Bonsall, R. W., and Michael, R. P. (1992). Immunohistochemical labeling of androgen receptors in the brain of rat and monkey. Life Sci. 50:409-417.

Commins, D. and YAHR, P. (1985). Autoradiographic localization of estrogen and androgen receptors in the sexually dimorphic area and other regions of the gerbil brain. J. Comp. Neurol. 231:473-489.

DoherTy, P. C. and Sheridan, P. J. (1981). Uptake and retention of androgen in neurons of the brain of the male Syrian hamster. Brain Res. 219:327-334.

ElLIS, G. B. and TUREK, F. W. (1980). Photoperiod-induced change in responsiveness of the hypothalamicpituitary axis to exogenous 5a-dihydrotestosterone and 17B-estradiol in castrated male hamsters. Neuroendocrinology 31:205-209.

Fiorelli, G., Zoppl, S., Kohen, F., and MotTa, M. (1989). Synergistic effect of testosterone and a luteinizing hormone-releasing hormone agonist on androgen receptor content in the ventral prostate of castrated rats. Steroids 53:195-217. 
Fox, C. A., Ross, L. R., HaNDA, R. J., and JACOBSEN, C. D. (1991). Localization of cells containing estrogen receptor-like immunoreactivity in the Brazilian opossum brain. Brain Res. 546( 1):96-105.

Gasc, J. -M., Delahaye, F., and Baulieu, E. -E. (1989). Compared intracellular localization of the glucocorticosteroid and progesterone receptors: an immunocytochemical study. Exp. Cell Res. 181:492504.

Gorski, J., TofT, D., Shyamala, G., Smith, D., and Notides, A. (1968). Hormone receptors: studies on the interaction of estrogens with the uterus. Recent Prog. Horm. Res. 24:45-80.

Gorski, J., Welshons, W. V., Sakai, D., Hansen, J., Walent, J., Kasis, J., Shull, J., Stack, G., and CAMPEN, C. (1986). Evolution of a model of estrogen action. Recent Prog. Horm. Res. 42:297-329.

Grino, P. B., GrifFin, J. E., and Wilson, J. D. ( 1990 ). Testosterone at high concentrations interacts with the human androgen receptor similarly to dihydrotestosterone. Endocrinology 126:1 165-1 172.

Guiochon-Mantel, A., Lescop, P., ChristinMaitre, S., Loosfelt, H., Perrot-Applanat, M., and Milgrom, E. (1991). Nucleoplasmic shuttling of the progesterone receptor. $E M B O . J .10(12): 3851-$ 3859.

Handa, R. J., Reid, D. L., and Resko, J. A. (1986). Androgen receptors in brain and pituitary of female rats: cyclic changes and comparisons with the male. Biol. Reprod. 34:293-303.

Handa, R. J., Stadelman, H. L., and Resko, J. A. (1987). Effect of estrogen on androgen receptor dynamics in female rat pituitary. Endocrinology 121:8489.

Husman, D. A., Wilson, C. M., MCPhaul, M. J., TilLEY, W. D., and WILSON, J. D. (1990). Antipeptide antibodies to two distinct regions of the androgen receptor localize the receptor protein to the nuclei of target cells in the rat and human prostate. Endocrinology 126(5):2359-2368.

Hutchison, R. E., Hutchison, J. B., Steimer, T., Steel, E., Powers, J. B., Walker, A. P., Herbert, J., and HASTINGS, M. H. (1991). Brain aromatization of testosterone in the male Syrian hamster: effects of androgen and photoperiod. Neuroendocrinology 53:194-203.

JANNE, O. A. and Shan, L. -X. (1990). Structure and function of the androgen receptor. Ann. NY Acad. Sci. 546:81-91.

liposits, Z., Kallo, I., Coen, C. W., Paull, W. K., and FLERKO, B. (1990). Ultrastructural analysis of estrogen receptor immunoreactive neurons in the medial preoptic area of the female rat brain. Histochemistry 93:233-239.

Lubahn, D., JosePh, D., Sullivan, P., Willard, H., French, F., and Wilson, E. (1988). Cloning of human androgen receptor complementary DNA and localization to the X Chromosome. Science 240:327330.
Karsch, F. J., Dierschke, D. J., WeICK, R. F., YamaJI, T., HotCHKISS, J., and KNOBIL, E. (1973). Positive and negative feedback control by estrogen of luteinizing hormone secretion in the rhesus monkey. Endocrinology 92:799-804.

KING, W. J. and Greene, G. L. (1984). Monoclonal antibodies localize oestrogen receptor in the nuclei of target cells. Nature 307:745-474.

KrEY, L. C. and MCGINNis, M. Y. (1990). Time courses of the appearance/disappearance of nuclear androgen + receptor complexes in the brain and adenohypophysis following testosterone administration/ withdrawal to castrated male rats: relationships with gonadotropin secretion. J. Steroid Biochem. Mol. Biol. 35(3-4):403-408.

Menard, C. S. and Harlan, R. E. (1992). Regulation of androgen receptor immunoreactivity by anabolic steroids in intact and castrated male rat brains. Soc Neurosci. Abstr. 18:546 (abstract no. 229.9).

MoRIN, L. and ZuCKER, I. ( 1978 ). Photoperiodic regulation of copulatory behavior in the male hamster. $J$. Endocrinol. 77:249-258.

Powers, J. B., Bergondy, M. L., and Matochik, J. A. (1985). Male hamster sociosexual behaviors: effects of testosterone and its metabolites. Physiol. Behav. 35:607-616.

Prins, G. S., Birch, L., and Greene, G. L. (1991). Androgen receptor localization in different cell types of the adult rat prostate. Endocrinology 129:31873199.

ROSELli, C. E. (1991). Sex differences in androgen receptors and aromatase activity in microdissected regions of the rat brain. Endocrinology 128:1310-1316.

Roselli, C. E., Handa, R. J., and Resko, J. A. (1989). Quantitative distribution of nuclear androgen receptors in microdissected areas of the rat brain. Neuroendocrinology 49:449-453.

SACHS, B. D. and MeISEL, R. L. (1988). The physiology of male sexual behavior. In: The Physiology of Reproduction. E. Knobil and J. D. Neill, eds. Raven Press, NY, pp. 1393-1486.

SaR, M., Lubahn, D. B., French, F. S., and Wilson, E. M. (1990). Immunohistochemical localization of the androgen receptor in rat and human tissues. Endocrinology 127(6):3180-3184.

SAR, M. and STUMPF, W. E. (1973). Autoradiographic localization of radioactivity in the rat brain after the injection of 1,2-3H-testosterone. Endocrinology 92:251-256.

SHERIDAN, P. J. ( 1978). Localization of androgen- and estrogen-concentrating neurons in the diencephalon and telencephalon of the mouse. Endocrinology 103:1328-1334.

Simerly, R. C., Chang, C., Muramatsu, M., and SWANSON, L. W. (1990). Distribution of androgen and estrogen receptor mRNA-containing cells in the rat brain: an in situ hybridization study. J. Comp. Neurol. 294:76-95.

Stankov, B., Lucini, V., Snochowski, M., CozzI, B., 
Fumagalli, P., Maccarinelli, G., and Fraschini, F. (1989). Cytosolic androgen receptors in the neuroendocrine tissues of the golden hamster: influence of photoperiod and melatonin treatment. Endocrinology 125(3):1742-1744.

SwanN, J. M. and Turek, F. W. (1988). Transfer from long to short days reduces the frequency of pulsatile luteinizing hormone release in intact but not in castrated male golden hamsters. Neuroendocrinology 47(4):343-349.

SYMS, A. J., NorRis, J. S., PANKO, W. B., and SMITH, R. G. (1985). Mechanism of androgen receptor augmentation. J. Biol. Chem. 260:455-461.

Tamarkin, L., Hutchison, J. S., and Goldman, B. D. (1976). Regulation of serum gonadotropins by photoperiod and testicular hormones in the Syrian hamster. Endocrinology 99:1528-1533.

TaN, J., Joseph, D. R., Quarmby, V. E., Lubahn, D. B., Sar, M., French, F. S., and Wilson, E. M. (1988). The rat androgen receptor: primary structure, autoregulation of its messenger ribonucleic acid, and immunocytochemical localization of the receptor protein. Mol. Endocrinol. 2(12):1276-1285.

TOBET, S. A., Bashan, M., Fox, T. O., and Baum, M. J.
(1991). Estrogen-receptor immunoreactive neurons in the forebrain of adult male and female ferrets. $A b$ stracts of the Twenty-first Annual Meeting of the Society for Neuroscience, New Orleans, LA, 1991 (Abstract 561.20).

Toyooka, K. T., ConNolly, P. B., Handa, R. J., and RESKO, J. A. (1991). Effects of exogenous steroids on androgen receptors in fetal guinea pig brain. Biol. Reprod. 44:1051-1062.

TUREK, F. W. (1977). The interaction of the photoperiod and testosterone in regulating serum gonadotropin levels in castrated male hamsters. Endocrinology 101: $1210-1215$.

Welshons, W. V., LiebermaN, M. E., and Gorski, J. (1984). Nuclear localization of unoccupied oestrogen receptors. Nature 307:747-749.

WoOD, R. I., Brabec, R. K., SWANN, J. M., and NewMAN, S. W. (1992). Androgen and estrogen receptorcontaining neurons in chemosensory pathways of the male Syrian hamster brain. Brain Res. 596:89-98.

WoOd, R. I. and NEwMaN, S. W. (1993). Mating activates androgen receptor-containing neurons in chemosensory pathways of the male Syrian hamster brain. Brain Res. (in press). 